\title{
Editorial
}

\section{Access to tax treaties}

\author{
J. David B. Oliver, Deloitte Haskins \& Sells, London
}

Tax treaties are negotiated and entered into in order to modify in certain circumstances the provisions of the domestic tax law of the respective countries. The only persons entitled to claim the benefit of a treaty are the residents of one or other of the respective countries: residents of third states are not generally speaking entitled to the benefit of the treaty. What constitutes residence for the purpose of the treaty is set out and defined in the treaty itself and may often have been determined as liability to tax in the particular state through a purely formal qualification such as the place of incorporation. Other limitations and restrictions on the application of the treaty will derive from requirements that the person claiming the benefit of the treaty should also be the 'beneficial owner' of the income in question or that he should be 'subject to tax' in respect fo that income. Provided that the resident of the contracting state complies with these requirements as set out in a particular treaty, then he is entitled to the benefit of the treaty. If one or both of the contracting states feel that he is claiming the benefit of the treaty in circumstances where he is not entitled, then it is up to them to refuse the claim or to renegotiate the terms of the treaty. In this sense a person's use of a treaty can never be said to be 'improper'. Either the treaty applies or it does not.

The OECD Committee on Fiscal Affairs has expressed the general view that ' . . the use of treaties is improper where a person (whether or not a resident of a contracting state), acts through a legal entity created in a state primarily to obtain treaty benefits which would not be available directly to such person.' This approach to the matter reflects some of the motive tests which some domestic tax jurisdictions might apply in analysing the effect of a transaction for tax purposes. Such tests may be based on a general concept of the abuse of rights, the introduction of a business purpose test or an analysis which depends on the substantial effect of the transaction. These tests become difficult to apply in some types of transaction, for example financing transactions, where the existence of a treaty may itself assist the free flow of funds and reduce the ultimate cost to the borrower. Therefore to term the application of tax treaties as being proper or improper, or the improper use itself as being 'treaty shopping', can be said to introduce somewhat perjorative phrases into a situation where the immediate issue is 'Does this treaty apply in this situation?' and the ultimate issue is: 'Whom did the contracting states intend to benefit from the conclusion of their treaty and does the treaty reflect that intention?'.

In any debate as to whether the qualification for the application of treaties should be more tightly drawn, with provisions such as Article 16 of the US Model Income Tax Treaty or provisions along the lines of those on the repayment of tax credit on dividends seen in the UK/Dutch and UK/Swiss Treaties, perhaps some further attention might be paid to the policing of the existing use of treaties. Certification that the taxpayer is entitled to the benefit of the treaty has long been required by many countries and it is interesting that one of the countries which does not practise extensive certification - the United States - is also the country which is most critical of the use of treaties by those whom it does not regard as entitled to their benefit. 